\title{
Climate Change Impacts of Electricity Generated at a Waste-to-Energy Facility
}

\section{Supporting Information}

Alyssa R. Pfadt-Trilling ${ }^{\mathrm{a}}$, Timothy A. Volk ${ }^{\mathrm{b} *}$, Marie-Odile P. Fortier ${ }^{\mathrm{c}}$

${ }^{\mathrm{a} D i v i s i o n}$ of Environmental Science

State University of New York College of Environmental Science and Forestry 202 Baker Laboratory, One Forestry Drive

Syracuse, NY, USA 13210

${ }^{b}$ Department of Sustainable Resources Management

State University of New York College of Environmental Science and Forestry 306 Bray Hall, One Forestry Drive

Syracuse, NY, USA 13210

${ }^{c}$ Department of Civil and Environmental Engineering

University of California - Merced

5200 North Lake Road

Merced, CA, USA 95343

*Corresponding Author:

Timothy A. Volk

Department of Sustainable Resources Management

State University of New York College of Environmental Science and Forestry

One Forestry Drive

Syracuse, NY, USA 13210

Email: tavolk@esf.edu

Number of Pages: 11

Number of Tables: 2

Number of Figures: 4 


\section{Combustion Emissions Manual Calculations:}

To determine the LCCCI of a system that involves a fuel stream comprised of both biomass and non-biogenic materials, we have distinguished between climate-forcing and climate-neutral emissions. Climate-forcing emissions are defined as all $\mathrm{CO}_{2}$ emissions from the combustion of non-biomass materials (i.e., fossil-based emissions), as well as all $\mathrm{CH}_{4}$ and $\mathrm{N}_{2} \mathrm{O}$ emissions regardless of biogenic or non-biogenic origin. Climate-neutral emissions are defined solely as the $\mathrm{CO}_{2}$ emissions resulting from combusting biomass. The notion of biogenic $\mathrm{CO}_{2}$ emissions as climate-neutral rests on the fact that the same amount of $\mathrm{CO}_{2}$ fixed from the atmosphere is emitted upon combusting biomass that fits the necessary temporal horizon. All emissions are normalized to $\mathrm{CO}_{2 \text { eq }}$ on a 100 -year horizon

The GHG emissions resulting from combustion of MSW were derived from the recorded total emissions for the year 2017, which are separated into biogenic and non-biogenic $\mathrm{CO}_{2}$, and $\mathrm{CH}_{4}$ and $\mathrm{N}_{2} \mathrm{O}$ emissions by the CEMS. ${ }^{1,2}$ The facility reported total 2017 combustion GHG emissions to be $344,717,300 \mathrm{~kg} \mathrm{CO}_{2}$, of which 148,288,400 kg was fossil-based and 196,488,900 $\mathrm{kg}$ originated from biomass, as well as $121,620 \mathrm{~kg} \mathrm{CH}_{4}$ and 15,963 $\mathrm{kg} \mathrm{N}_{2} \mathrm{O}$. While most of the literature on WTE reviewed for this paper did not include this distinction between GHG species emitted from the combustion of biomass, it has been previously suggested that $\mathrm{CH}_{4}$ and $\mathrm{N}_{2} \mathrm{O}$ emissions should be accounted for separately in assessing biomass fuel sources. ${ }^{3-5}$ The facility also reported processing $321,798,385 \mathrm{~kg}$ of MSW, comprised of approximately $60 \%$ biomass and $40 \%$ mixed plastics and other non-biomass materials by mass. To keep the distinction between climate-forcing and climate-neutral emissions, this data was used to calculate three values: the climate-forcing emissions resulting from combusting $1 \mathrm{~kg}$ of non-biomass (fossil-based) MSW, the climate-neutral emissions resulting from combusting $1 \mathrm{~kg}$ of biomass MSW, and the climateforcing emissions resulting from combusting $1 \mathrm{~kg}$ of biomass MSW. The emissions were weighted by dividing the total biogenic $\mathrm{CO}_{2}$ emissions (in $\mathrm{kg}$ ) by the $60 \%$ of the mass of MSW reported to be biomass, and the fossil-based $\mathrm{CO}_{2}$ emissions divided by the remaining $40 \%$ of the waste estimated to be mostly mixed plastics. The $\mathrm{CH}_{4}$ and $\mathrm{N}_{2} \mathrm{O}$ emissions were normalized to $\mathrm{CO}_{2 e q}$ using the EPA's 100 year horizon for $\mathrm{GWP}^{6}$ and similarly divided by the masses of waste reported to be fossil-based vs. biomass. The fossil-based normalized emissions were added to fossil-based $\mathrm{CO}_{2}$ emissions for a single combustion value in $\mathrm{CO}_{2 \mathrm{eq}}$, while the normalized biogenic emissions were kept separated for two distinct process equations: climate neutral and climate forcing combustion emissions.

Combustion emission values were calculated to be $1.176 \mathrm{~kg} \mathrm{CO} 2 \mathrm{eq} / \mathrm{kg}$ non-biomass MSW combusted (fossil-based emissions). Biogenic GHG emissions were separated as climateneutral $\mathrm{CO}_{2}$ emissions: $1.018 \mathrm{CO}_{2 \mathrm{eq}} / \mathrm{kg}$ biomass MSW combusted, and climate-forcing $\mathrm{CO}_{2 \mathrm{eq}}$ emissions: $0.0242 \mathrm{~kg} \mathrm{CO} 2 \mathrm{eq} / \mathrm{kg}$ biomass MSW combusted. These values closely agree with figures reported by Bahor et al, who determined an average impact (before weighting biogenic and fossil $\mathrm{CO}_{2}$ ) for electricity from MSW combustion to be $1.1 \mathrm{~kg} \mathrm{CO}_{2 \mathrm{eq}} / \mathrm{kg}$ waste combusted ${ }^{7}$, and an IPCC special report, which calculated a range of 0.7 to $1.2 \mathrm{~kg} \mathrm{CO} 2 \mathrm{eq} / \mathrm{kg}$ waste combusted. ${ }^{5}$ For both scenarios, only these climate forcing emissions are included in our reported LCCCI results.

\section{Calculations:}

All calculations based on 2017 data for full calendar year.

Total MSW processed $=321,798,385 \mathrm{~kg}$ 
Fossil-derived $\mathrm{CO}_{2}=148,228,400 \mathrm{~kg} \mathrm{CO} 2$

Biogenic $\mathrm{CO}_{2}=196,488,900 \mathrm{~kg} \mathrm{CO} 2$

$\mathrm{CH}_{4}$ as $\mathrm{CO}_{2 \mathrm{eq}}=3,040,500 \mathrm{~kg} \mathrm{CO}$ 2eq $(100$ year horizon)

$\mathrm{N}_{2} \mathrm{O}$ as $\mathrm{CO}_{2 \mathrm{eq}}=4,756,900 \mathrm{~kg} \mathrm{CO}_{2 \mathrm{eq}}(100$ year horizon)

Total normalized $\mathrm{CH}_{4}$ and $\mathrm{N}_{2} \mathrm{O}=7,797,400 \mathrm{~kg} \mathrm{CO}_{2 \text { eq }}$

Biomass MSW $=(0.6)(321798385)=193,079,031 \mathrm{~kg} \mathrm{MSW}$

Fossil-derived MSW $=(0.4)(321798385)=128,719,354 \mathrm{~kg} \mathrm{MSW}$

Biogenic $\mathrm{CO}_{2}$ combustion emissions $=196488900 \mathrm{~kg} \mathrm{CO}_{2} / 193079031 \mathrm{~kg} \mathrm{MSW}=1.017660483$ $\mathrm{kg} \mathrm{CO}_{2} / \mathrm{kg}$ biomass MSW

Biomass-derived normalized non- $\mathrm{CO}_{2}$ emissions $=\left(7797400 \mathrm{~kg} \mathrm{CO}_{2 \mathrm{eq}}\right)(0.6)=4,678,440 \mathrm{~kg} \mathrm{CO}_{2 \mathrm{eq}}$

Biomass-derived climate-forcing combustion emissions $=4678440 \mathrm{~kg} \mathrm{CO} 2 \mathrm{eq} / 193079031 \mathrm{~kg}$ biomass MSW $=0.02423066459 \mathrm{~kg} \mathrm{CO}$ 2eq $/ \mathrm{kg}$ biomass $\mathrm{MSW}$

Fossil-derived normalized non- $\mathrm{CO}_{2}$ emissions $=\left(7797400 \mathrm{~kg} \mathrm{CO}_{2 \mathrm{eq}}\right)(0.4)=3,118,960 \mathrm{~kg} \mathrm{CO}_{2 \mathrm{eq}}$

Fossil-derived $\mathrm{CO}_{2 \text { eq }}$ combustion emissions $=\left(148228400 \mathrm{~kg} \mathrm{CO}_{2} / 128719354 \mathrm{~kg} \mathrm{MSW}\right)+$ $(3118960 \mathrm{~kg} \mathrm{CO} 2$ eq $/ 128719354 \mathrm{~kg} \mathrm{MSW})=1.175793347 \mathrm{~kg} \mathrm{CO}_{2 \mathrm{eq}} / \mathrm{kg}$ non-biomass MSW

\section{System Boundary Definition}

Excluded from the system boundary are the pre-existing infrastructure and equipment that outlast the temporal scope of this study. The facility has been operational since 1994 and has no plans for decommissioning in the near future; the current contract remains in effect until $2035 .{ }^{8}$ Manufacturing of equipment necessary for operations has been excluded as all combustion-driven power plants generally require these materials and therefore it does not affect comparison amongst alternatives where they are also excluded. This method of excluding long-lasting infrastructure and equipment from a system boundary is well-established in LCA literature on WTE plants, as it is often found to be relatively insignificant to the overall life cycle impact per functional unit. ${ }^{9,10}$ Including power plant infrastructure emissions in LCAs on conventional natural gas technology was reported to contribute approximately $1 \mathrm{~g}$ of $\mathrm{CO}_{2 \mathrm{eq}} / \mathrm{kWh}$ by NREL's LCA Harmonization Project ${ }^{11}$ not nearly enough to influence comparisons due to the range of life cycle GHG emissions determined for electricity from natural gas power plants by this effort. ${ }^{12}$ The use of water circulating between the boiler and condenser in the combustion process and high-temperaturerated plastic bag filters for capturing particulate matter were also excluded from the system boundary on the basis that these processes accounted for an insignificant (far less than 1\%) portion of the overall LCCCI. 


\section{List of Assumptions and Limitations}

1. Water use does not have a significant impact on LCCCI results. The facility has a closed-loop system for water, with no discharge to a natural body of water. Water has been left out as a material product and the impact not included on the basis of this assumption. Manual calculations using base-case variables determined that adding the LCCCI of water would add $0.000074 \mathrm{~kg} \mathrm{CO} 2 \mathrm{eq} /$ $\mathrm{kWh}$ to the baseline results. (Facility reports using approximately $0.4089 \mathrm{~kg}$ water $/ \mathrm{kg} \mathrm{MSW}$ ). ${ }^{13}$ Manual calculation was performed by converting to $\mathrm{kg}$ water/ $\mathrm{kWh}$ by baseline variable parameter where $1 \mathrm{~kg}$ MSW generates $0.6933 \mathrm{kWh}$, and using LCI values for water).

2. The high-tempered plastic bag filters do not have a significant impact on LCCCI results. The facility uses 3-6,000 bag filters changed approximately every 4 years, or approximately 1500 filters per year using the studied time-frame. ${ }^{2}$ Manual calculations using base-case variables determined that adding the LCCCI of the bag filters increased baseline results by $0.0000031227 \mathrm{~kg} \mathrm{CO}_{2 \mathrm{eq}} /$ $\mathrm{kWh}$, and so bag filters were excluded from the system boundary.

3. Net electrical-generation is a production of cumulative effects, and not primarily a result of the composition of the MSW processed. Although the physical composition of the MSW varies slightly from year to year, net electrical output does not appear to be strongly correlated based on examining historical data for the facility. Due to this assumption, net electrical generation was left as a stand-alone variable and not linked to the MSW composition. The data required for more detailed equations linking MSW composition and net electrical generation was not available for this facility.

4. Combustion emissions are reflective of the mass composition of MSW provided for the year 2017. The calculations detailed above are based on the assumption that separating the emissions recorded by the CEMS and weighting each to the mass composition of MSW described to the author is the most accurate method available to estimate emissions resulting from combustion of MSW. The values calculated for this facility are within ranges previously published.

5. The recovered ash used as a landfill cover does not have a quantifiable LCCCI. This co-product material serves a function in place of soil as a nightly cover, but has been left out of the system boundary beyond transportation to the landfill due to lack of available data as to whether this avoids emissions resulting from procuring soil. The authors assume that it is likely that there is no significant difference in GHG emissions that would affect the LCCCI results of this study.

6. After running the baseline LCA simulation and observing that the collection and transportation of MSW accounted for less than $0.5 \%$ of the total LCCCI per kWh of electricity generated, it was decided that calculating a more detailed transportation scenario by weighting transportation distances according to waste disposal rates based on population dynamics of the county was unnecessary.

7. The ash residue recovered after combustion (minus the recovered metals ultimately recycled) is used as a landfill cover in place of soil, where it does provide some functionality, but not one that is readily quantifiable in terms of GHG emissions avoidance, and so this was not considered as a coproduct or additional burden in system expansion. Instead, this mass of MSW was simply included in the range of MSW not sent to landfill, as it does not generate methane directly like MSW managed in a landfill. 
8. The use of a single point value from EcoInvent 3 for the avoided landfilling emissions activities and a separate value for fugitive emissions ${ }^{14}$ assumes that these values are accurately representative of the GHG emissions the MSW would generate at a landfill if not incinerated. While sources in the SimaPro databases are thoroughly vetted and scientifically sound, there is ample research demonstrating that landfilling emissions are highly uncertain, ${ }^{15-19}$ and that emission rates are site-specific. ${ }^{18-21}$ A number of climatic, technological, and logistic variables influence the life cycle GHG emissions of MSW sent to landfill, including the composition of the waste down to individual food items ${ }^{16,20}$, and how the waste is compacted ${ }^{21}$, among others. As this system expansion scenario is theoretical, and waste from Onondaga County is not landfilled, it would be purely speculative to assume values for any of these variables. Conducting a sitespecific LCA of a local landfill is outside of the scope of this study, but may be the only way to gain an accurate understanding of the landfilling emissions specific to the region, given the MSW composition and technology utilized.

9. It is not possible to separate and/or quantify the distinction between uncertainty and variability ${ }^{22}$ in the LCA results as the key parameters are subject to both. For example, the transportation distance travelled during waste collection is both uncertain, in that it has been estimated using the likely distance points in the jurisdiction, and variable, based on how waste collection trucks make multiple stops, may change routes, and/or experience traffic delays, increasing fuel consumption. The composition of the waste, which proved to be a highly influential variable parameter, also varies somewhat based on behavior and consumption patterns, in addition to being uncertain due to how it is tracked. Similarly, the activities that contribute to operational emissions including material amounts and processes involving heavy equipment involve elements of uncertainty and variability that cannot be distinguished. 


\section{References for the Supporting Information}

1. Covanta. Emissions Information. https://www.covanta.com/Sustainability/EnvironmentalOverview/Emissions-Information. Accessed July 23, 2020.

2. Facility Employee. Interview. 2018.

3. Gillenwater M. CALCULATION TOOL FOR DIRECT EMISSIONS FROM STATIONARY COMBUSTION A WRI/ WBCSD Tool Michael Gillenwater Environmental Resources Trust.; 2005.

4. Seltenrich N. Emerging Waste-to-Energy Technologies: Solid Waste Solution or Dead End? Environ Health Perspect. 2016;124(6):A106-A111. doi:10.1289/ehp.124-A106

5. IPCC. Waste. In: Penman J, Kruger D, Galbally I, Hiraishi, T Nyenzi, B Emmanul, S Buendia, L Hoppaus, R Martinsen, T Meijer, J Miwa, K Tanabe, K, eds. IPCC Good Practice Guidance and Uncertainty Management in National Greenhouse Gas Inventories. ; 2000. https://www.ipcc.ch/site/assets/uploads/2018/03/5_Waste-1.pdf. Accessed July 23, 2020.

6. U.S. Environmental Protection Agency. Greenhouse Gas Equivalencies Calculator | Energy and the Environment | US EPA. https://www.epa.gov/energy/greenhouse-gasequivalencies-calculator. Accessed July 23, 2020.

7. Bahor B, Van Brunt M, Weitz K, Szurgot A. Life-Cycle Assessment of Waste Management Greenhouse Gas Emissions Using Municipal Waste Combustor Data. $J$ Environ Eng. 2010;136(8):749-755. doi:10.1061/(ASCE)EE.1943-7870.0000189

8. Knauss T. OCRRA approves 20-year renewal of trash plant contract, will burn 9 percent more. Syracuse.com. https://www.syracuse.com/news/2014/11/ocrra_approves_20year_renewal_of_trash_plant_contract_will_burn_9_percent_more.html. Published 2019. Accessed July 23, 2020.

9. Finnveden G, Johansson J, Lind P, Moberg Å. Life cycle assessment of energy from solid waste - Part 1: General methodology and results. In: Journal of Cleaner Production. Vol 13. Elsevier; 2005:213-229. doi:10.1016/j.jclepro.2004.02.023

10. Kaplan PO, Decarolis J, Thorneloe S. Is it better to burn or bury waste for clean electricity generation? Environ Sci Technol. 2009;43(6):1711-1717. doi:10.1021/es802395e

11. Heath GA, O’Donoughue P, Whitaker M. Life Cycle GHG Emissions from Conventional Natural Gas Power Generation: Systematic Review and Harmonization (Presentation) (Conference) | OSTI.GOV. https://www.osti.gov/biblio/1056750-life-cycle-ghgemissions-from-conventional-natural-gas-power-generation-systematic-reviewharmonization-presentation. Published 2012. Accessed July 23, 2020.

12. O'Donoughue PR, Heath GA, Dolan SL, Vorum M. Life Cycle Greenhouse Gas Emissions of Electricity Generated from Conventionally Produced Natural Gas. J Ind Ecol. 2014;18(1):125-144. doi:10.1111/jiec.12084

13. Miller AK. Onondaga County Resource Recovery Facility Annual Report of Facility Performance Operating Year 2012.; 2013. https://ocrra.org/wp- 
content/uploads/reports/wte-annual-report-110813.pdf. Accessed July 24, 2020.

14. Zhao H. Methane Emissions from Landfills.; 2019. http://gwcouncil.org/wpcontent/uploads/2019/06/Methane-Emissions-from-Landfills-Haokai-Zhao.pdf. Accessed November 28, 2020.

15. Laner D. The consideration of long-term emissions from landfills within life-cycle assessment. Waste Manag Res. 2009;27:463-470. doi:10.1177/0734242X09102335

16. Eriksson M, Strid I, Hansson PA. Carbon footprint of food waste management options in the waste hierarchy - A Swedish case study. J Clean Prod. 2015;93:115-125. doi:10.1016/j.jclepro.2015.01.026

17. Bogner J, Pipatti R, Hashimoto S, Diaz C, Mareckova K, Diaz L, Kjeldsen P, Monni S, Faaji A, Qingxian G, Tianzhu Z, Mohammed A.A, Sutamihardja R.T.M, Gregory R. Mitigation of global greenhouse gas emissions from waste: Conclusions and strategies from the Intergovernmental Panel on Climate Change (IPCC) Fourth Assessment Report. Working Group III (Mitigation). Waste Manag Res. 2008;26(1):11-32. doi:10.1177/0734242X07088433

18. Bogner J, Spokas K. Landfill CH4: Rates, fates, and role in global carbon cycle. Chemosphere. 1993;26(1-4):369-386. doi:10.1016/0045-6535(93)90432-5

19. Cusworth DH, Duren RM, Thorpe AK, Tseng E, Thompson D, Guha A, Newman S, Foster K, Miller C. Using remote sensing to detect, validate, and quantify methane emissions from California solid waste operations. Environ Res Lett. 2020;15(054012). doi:10.1088/1748-9326/ab7b99

20. Lee U, Han J, Wang M. Evaluation of landfill gas emissions from municipal solid waste landfills for the life-cycle analysis of waste-to-energy pathways. J Clean Prod. 2017;166:335-342. doi:10.1016/j.jclepro.2017.08.016

21. Izzati Othman K, Hashim H, Ting Tan S, Siong Ho C. Carbon Emission Pinch Analysis for Sustainable Landfill. In: CHEMICAL ENGINEERING TRANSACTIONS. Vol 56. ; 2017. doi:10.3303/CET1756087

22. Hauck M, Steinmann ZJN, Laurenzi IJ, Karuppiah R, Huijbregts MAJ. How to quantify uncertainty and variability in life cycle assessment: The case of greenhouse gas emissions of gas power generation in the US. Environ Res Lett. 2014;9(7):074005.

doi:10.1088/1748-9326/9/7/074005 
Table S1: Life cycle inventories used

\begin{tabular}{|c|c|c|c|}
\hline Category & Life cycle inventory & Units & Source \\
\hline \multirow{3}{*}{ Combustion } & $\begin{array}{lr}\text { Biomass } & \mathrm{CO}_{2} \\
\text { combustion emissions }\end{array}$ & $\begin{array}{ll}\mathrm{kg} & \mathrm{CO}_{2} / \mathrm{kg} \text { biomass } \\
\text { MSW combusted }\end{array}$ & $\begin{array}{l}\text { Combustion emissions } \\
\text { manual calculations }\end{array}$ \\
\hline & $\begin{array}{l}\text { Biomass non- } \mathrm{CO}_{2} \\
\text { combustion emissions } \\
\text { (climate-forcing } \\
\text { emissions) }\end{array}$ & $\begin{array}{l}\mathrm{kg} \mathrm{CO}_{2 \mathrm{eq}} / \mathrm{kg} \text { biomass } \\
\text { MSW combusted }\end{array}$ & $\begin{array}{l}\text { Combustion emissions } \\
\text { manual calculations }\end{array}$ \\
\hline & $\begin{array}{l}\text { Non-biomass } \\
\text { combustion emissions }\end{array}$ & $\begin{array}{lr}\mathrm{kg} \quad \mathrm{CO}_{2 \mathrm{eq}} / \mathrm{kg} & \text { non- } \\
\text { biomass } & \text { MSW } \\
\text { combusted } & \\
\end{array}$ & $\begin{array}{l}\text { Combustion emissions } \\
\text { manual calculations }\end{array}$ \\
\hline \multirow{4}{*}{ Transportation } & Single-unit truck & $\mathrm{kg} \mathrm{CO}_{2 \mathrm{eq}} / \mathrm{kg} \mathrm{km}$ & USLCI \\
\hline & Front loader & $\mathrm{kg} \mathrm{CO}$ 2eq/hour & USLCI \\
\hline & Combination truck & $\mathrm{kg} \mathrm{CO}_{2 \mathrm{eq}} / \mathrm{kg} \mathrm{km}$ & USLCI \\
\hline & Refuse truck & $\mathrm{kgCO}_{2 \mathrm{eq}} / \mathrm{kg} \mathrm{km}$ & USLCI \\
\hline \multirow{4}{*}{ Materials } & Ammonia & $\mathrm{kg} \mathrm{CO} 2 \mathrm{eq} / \mathrm{kg}$ ammonia & Ecoinvent 3 \\
\hline & Activated carbon & $\begin{array}{l}\mathrm{kg} \mathrm{CO} \mathrm{CO}_{2 \mathrm{eq}} / \mathrm{kg} \text { activated } \\
\text { carbon }\end{array}$ & Agri-footprint \\
\hline & Lime & $\mathrm{kg} \mathrm{CO} 2 \mathrm{eq} / \mathrm{kg}$ lime & Ecoinvent 3 \\
\hline & Bag filters & $\mathrm{kg} \mathrm{CO}_{2 \mathrm{eq}} / \mathrm{bag}$ filter & Ecoinvent 3 \\
\hline \multirow{3}{*}{ Grid Energy } & \begin{tabular}{ll|}
$\begin{array}{l}\text { Regional } \\
\text { electricity }\end{array}$ & grid \\
\end{tabular} & $\mathrm{kg} \mathrm{CO} 2 \mathrm{eq} / \mathrm{kWh}$ & USLCI \\
\hline & Natural gas & $\mathrm{kg} \mathrm{CO} \mathrm{CO}_{2 \mathrm{q}} / \mathrm{m}^{3} \mathrm{gas}$ & Ecoinvent 3 \\
\hline & $\begin{array}{|lll|}\begin{array}{l}\text { Natural } \\
\text { annually }\end{array} & \text { gas } & \text { used } \\
\end{array}$ & $\mathrm{kg} \mathrm{CO}$ 2eq/year & $\begin{array}{l}\text { Primary data provided } \\
\text { by OCRRA }\end{array}$ \\
\hline \multirow{5}{*}{$\begin{array}{l}\text { Avoided } \\
\text { Processes }\end{array}$} & Ferrous metal recycling & $\begin{array}{lrl}\mathrm{kg} & \mathrm{CO}_{2 \mathrm{eq}} / \mathrm{kg} & \text { ferrous } \\
\text { metal recycled } & \\
\end{array}$ & Ecoinvent 3 \\
\hline & $\begin{array}{l}\text { Nonferrous (aluminum) } \\
\text { metal recycling }\end{array}$ & $\begin{array}{l}\mathrm{kg} \mathrm{CO}_{2 \mathrm{eq}} / \mathrm{kg} \text { aluminum } \\
\text { recycled }\end{array}$ & Ecoinvent 3 \\
\hline & \begin{tabular}{ll|}
$\begin{array}{l}\text { MSW } \\
\text { activities }\end{array}$ & landfilling \\
\end{tabular} & $\begin{array}{lll}\mathrm{kg} & \mathrm{CO}_{2 \mathrm{eq}} / \mathrm{kg} & \mathrm{MSW} \\
\text { landfilled }\end{array}$ & Ecoinvent 3 \\
\hline & $\begin{array}{ll}\begin{array}{l}\text { Fugitive } \\
\text { emissions }\end{array} & \text { methane } \\
\end{array}$ & $\mathrm{kg} \mathrm{CH}_{4} / \mathrm{kg} \mathrm{MSW}$ & Zhao $(2019)^{14}$ \\
\hline & Natural gas electricity & $\mathrm{kg} \mathrm{CO} 2 \mathrm{eq} / \mathrm{kWh}$ & $\begin{array}{l}\text { NREL Harmonization } \\
\text { Project }^{12}\end{array}$ \\
\hline
\end{tabular}




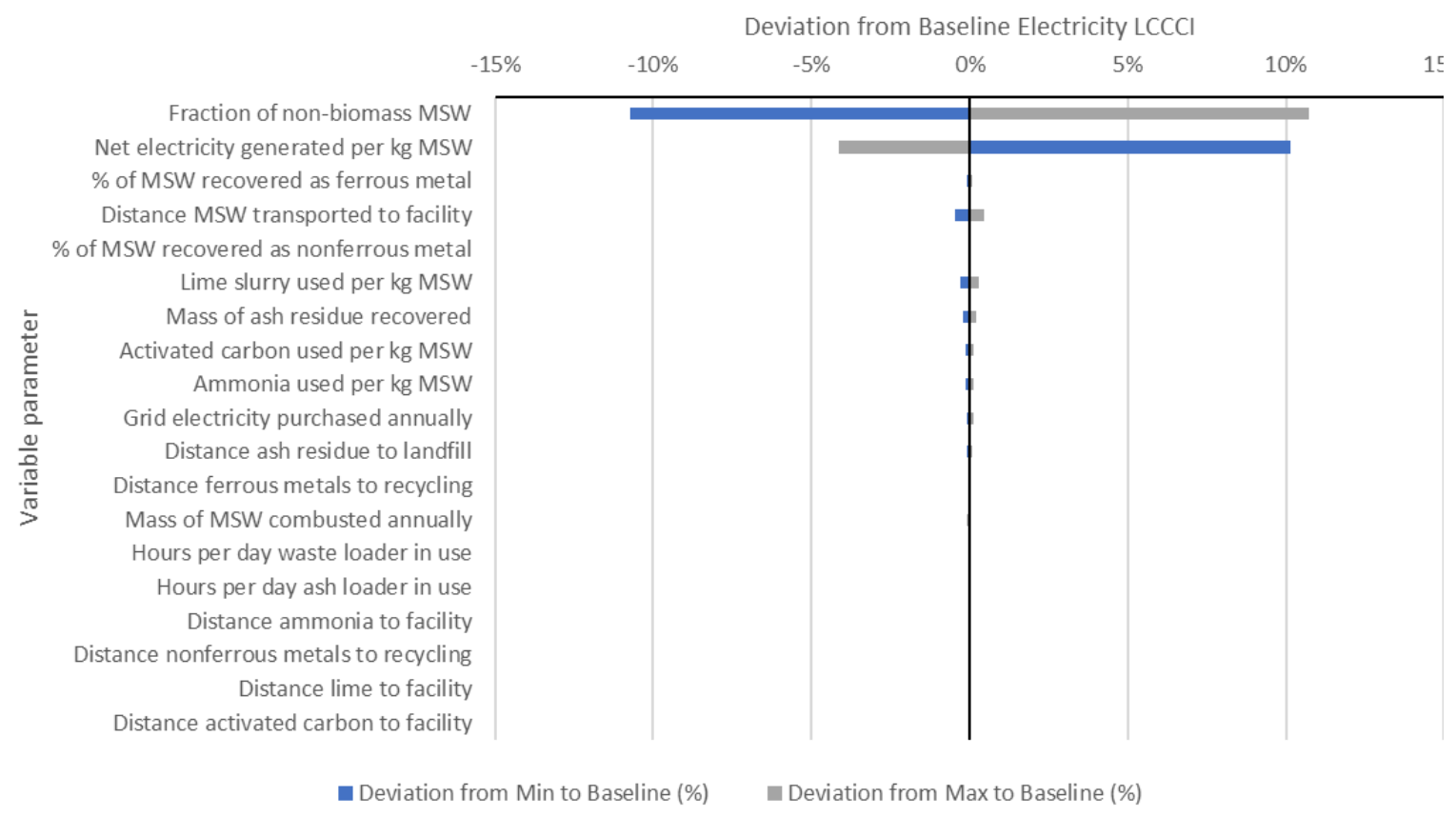

Figure S1. Changes from the baseline LCCCI values resulting from the sensitivity analyses for the Electricity Scenario for WTE at the Jamesville, NY facility.

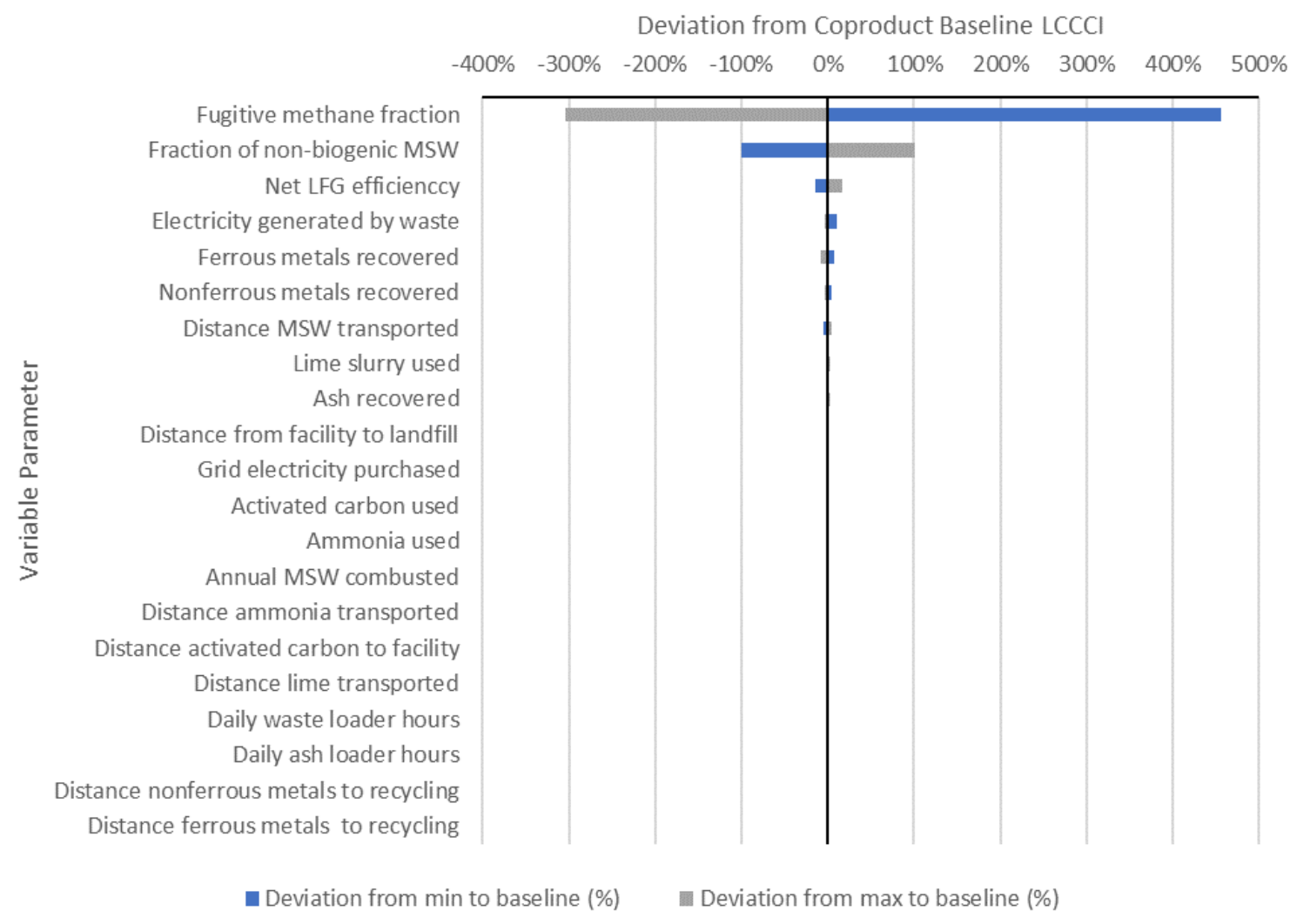

Figure S2. Changes from the baseline LCCCI values resulting from the sensitivity analyses for the Coproduct Scenario for WTE at the Jamesville facility. 


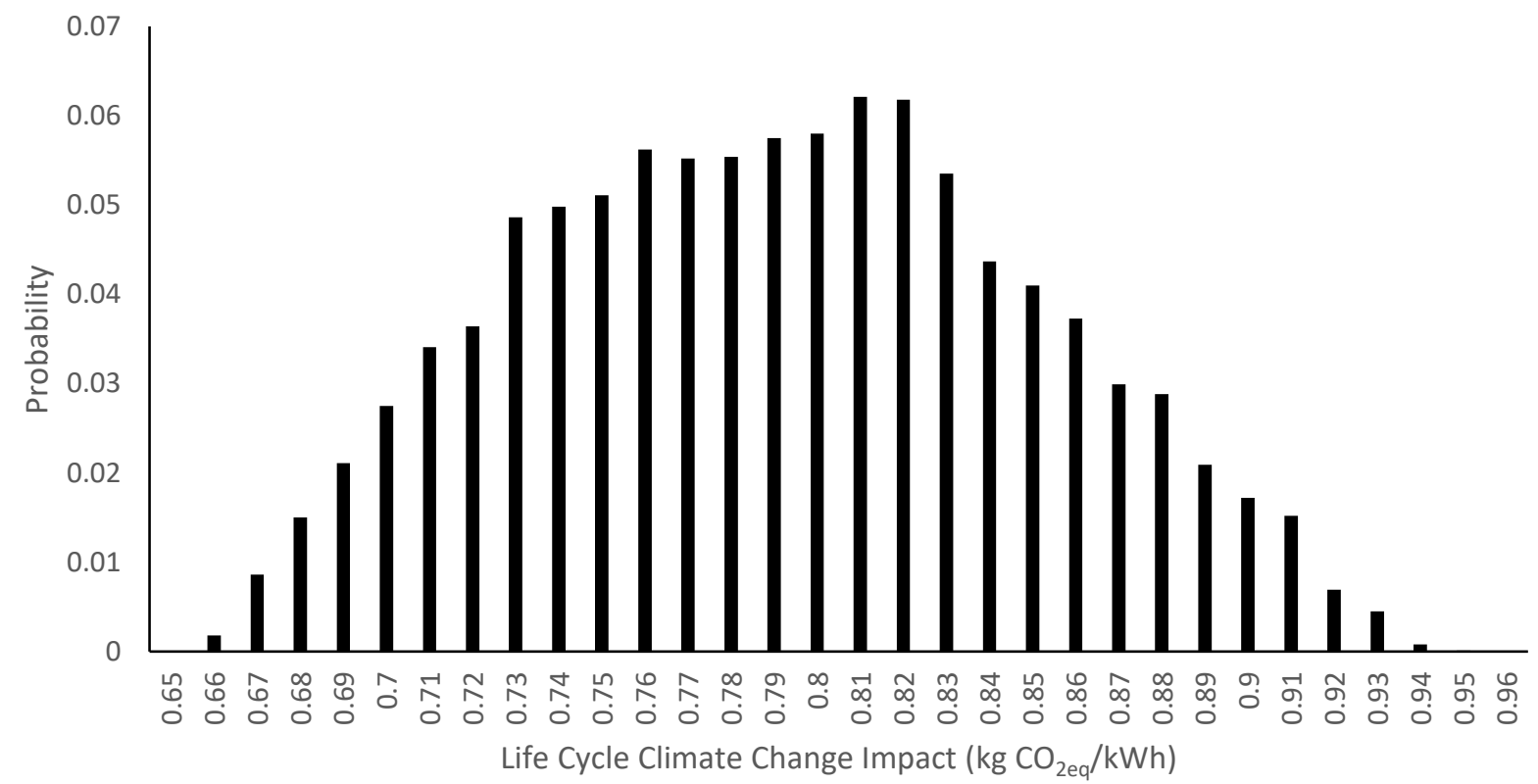

Figure S3. Monte Carlo frequency distributions for the Electricity scenario, based on 10,000 randomized simulations performed in Python 2.7 code.

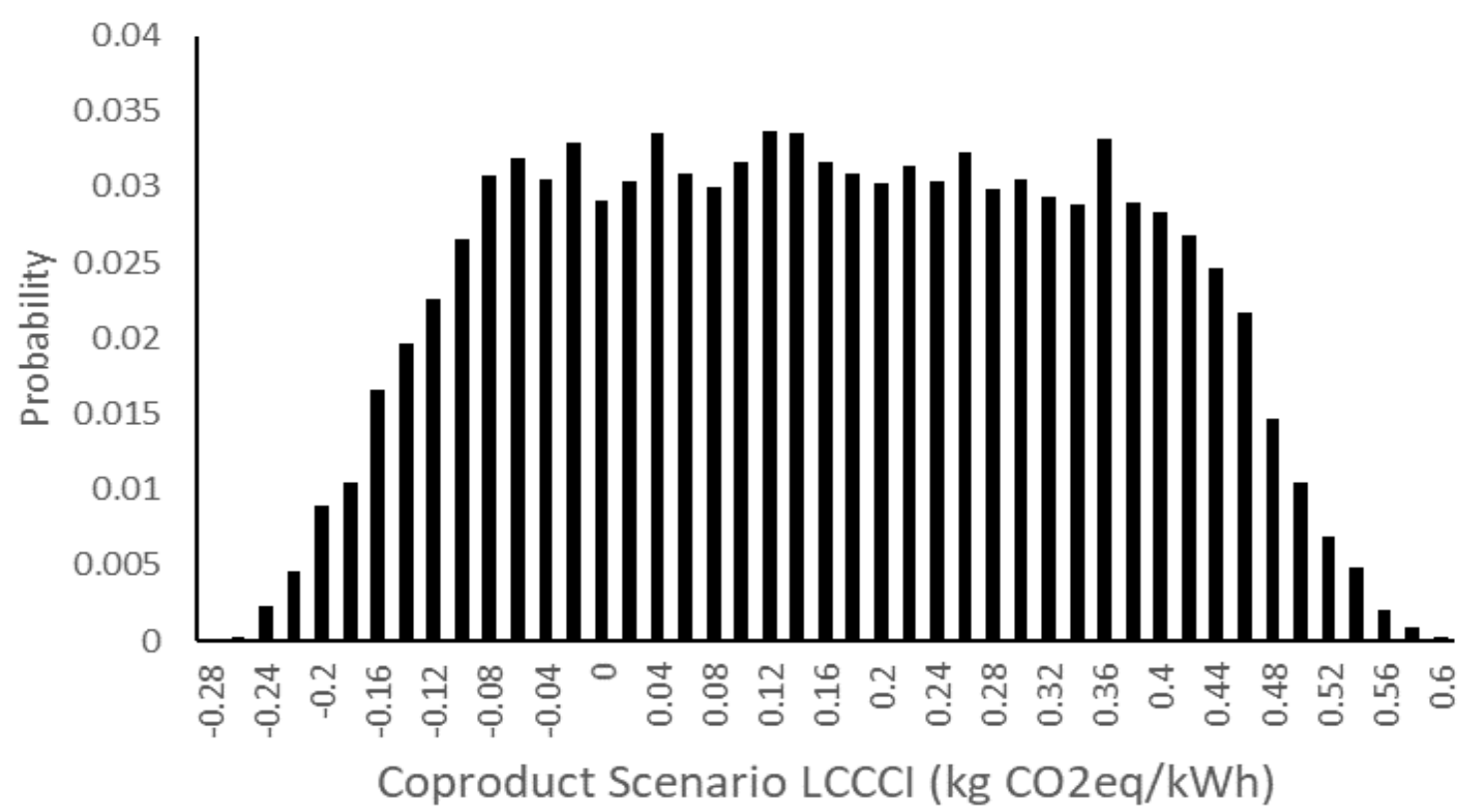

Figure S4. Monte Carlo frequency distributions for the Coproduct scenario, based on 10,000 randomized simulations performed in Python 2.7 code. 
Table S2. Descriptive statistics from the Monte Carlo analysis for each scenario.

\begin{tabular}{|l|l|l|}
\hline & $\begin{array}{l}\text { Electricity Scenario } \\
\text { (kg CO2eq/kWh) }\end{array}$ & $\begin{array}{l}\text { Coproduct Scenario } \\
\text { (kg CO2eq/kWh) }\end{array}$ \\
\hline Minimum LCCCI & 0.664 & -0.280 \\
\hline Maximum LCCCI & 0.951 & 0.593 \\
\hline Standard Deviation & 0.0592 & 0.192 \\
\hline 95\% Confidence Interval & 0.796 to 0.798 & 0.143 to 0.150 \\
\hline Median LCCCI & 0.797 & 0.146 \\
\hline Mean LCCCI & 0.797 & 0.149 \\
\hline Interquartile range & 0.0880 & 0.320 \\
\hline
\end{tabular}

